Chapter 20

\title{
PREVENTION OF DETERIORATION IN WATERFRONT STRUCTURES
}

\author{
George B. Knox \\ Navy Department \\ Bureau of Yards and Docks
}

The Bureau of Yards and Docks is greatly interested in prevention of deterioration and the preservation of marine structures such as wharves, piers, quay walls, mooring dolphins and various other structures which forn a part of all of our coastal Navel stations.

The Buream is what mey be called the "Public Works" agency for the Navy. It is responsible for the design and construction of structures that comprise the Naval Shore Hstabli shments which a re necessary to support our vast fleet. The marine structures are a large item in this great system of bases. When you consider the number of installations scattered all over the world you will realize that the engineers charged with the design, construction and maintenance of these port fam cilities are faced with great responsibilities. These installations present many problems - not only due to their vastness - but also bocause they are installed and must be maintained under all types of climactic conditions ranging from frigid to tropical.

The protection of timber structures against deterioration and destruction by marine borers has always been of major concern to builders of marine structures and to maintenance engineers.

In the early $1880^{\prime} \mathrm{s}$ a rather novel and original experiment in the control of marine borers was tried out by a New York inventor. This inventor owned a string of scows which he used in his business. They were attacked by Teredo. To prevent damage from the marine borer he is said to have meared the bottom and sides with coal tar and sprinkled orer it an even layer of Copenhagen Snuff. Being a hater of tobacco he believed that this world be the most disagreeable thing he could do to the Teredo. Unfortunately, however, for the experiment, the coal tar rubbed off in spots and the Teredo got in. There is no proof that the snuff was of any value in preventing Teredo attack. More scientific methods are now being used in the evaluation of protective measures against the attack of these animals.

The marine borers are found to some degree in all oceans. In other words, no place in the world where salt water occurs seems to be entire1y safe from their attack. They are even known to exist in freah water.

Some waters are highly infested while other waters appear to be only slightly infested, or even free of the marine borers. Those water which are highly infested sometimes become less infested. The marine borers apparently disappear. In waters which have shown no infestation, the marine borer may suddenly appear in large quantities and endanger the structures in that ares. 


\section{COASTAL ENGINEERING}

The migration of borers into harbors is being watched carefulzy through maintenance of control panels in various locations. A systematic replacement of these panels gives an indication of the seasons of attack, broeding periods in harbors and infestation of harbors which, up to now, have been free of marine borers.

These indicators also serve as a warning that attack may be occurring and gives maintenance engineers sufficient time to take remedial measures to prevent complete collapse of such structures. In some instences where such indicators have not been maintained, certain structures have suddenly collapsed without warning due to the inroads made on the structures by these organisms.

Short-time tests by no means guarantee that the harbor water in a certain area will continue to be free from any marine borer attacks. Therefore, the engineers and maintenance crews at no time can be sure of complete or continuing safety. Continuing and vigilant defense against the attack of marine borers must be provided for the timber harbor structures or they may be destroyed.

Harbor conditions may change from time to time due to change in sewer discharge and disposal of industrial wastes in a given area. For example, at a Navy pier on the kest Coast, it was felt that there would be no need for any treatment of the piles in that ares, inasmuch as other structures using untreated wood had been in place for many years. Nio consideration was given to the fact that adjacent to this area a pulp mill was in operation and its waste effluent was dumped into the harbor close in line with the structures. The harbor authorities and Fish and Wild Ilfe Service forced the pulp mill to extend their effluent line to the deeper portion of the harbor in order to prevent pollution which was injurious to fish life in that area. Within a short time marine borer attack progressed to such an extent that a large appropriation of funds was required to replace piling which hed been in place over the previous ten or fifteen years with no damage during the time.

Since the point of attack of marine borers lies between the water level and mudine on submerged timber, a. good many precautionary steps cen be taken in the design of wooden structures in marine locations. However, the precautions in design which may be taken should not give the builder or the maintenance engineer a sense of security against marine borer attack, for certain types of borers, known as the family Teredine or Teredinidae, enter the timbers by arilling tiny holes, then growing within the timber, and destroying the timber during their growth. The Teredinidue attack is generaliy more severe at the muline portion of the pile, but can occur at any point that is submerged. Sorface inspections often fail to detect such attack. 


\section{PREVENTION OF DETERIORATION IN WATERFRONT STRUCTURES}

Of course, the Crustacean type of borer, known as the Iimnoria family, can ordinarily be seen more readily on examination of piling and on timbers in that they burrow very close to the surface of the timber and the burrow shell cuts off, leaving a gradual surface erosion. Ons of the best ways to determine whether timber structures are being attacked by the Iimnoria is the hour-glass appearance of the piling mostly appearing at the waterline, but also may occur at the madine.

From numerous inspections of structures and the search of literature reporting on failures of marine structures it has been concluded that important and frequent causes of short service life of pilings may be listed somewhat in this order:

1. The use of timbers which do not lend themselves to acceptable treatment.

2. The use of a poor grade of preservative which does not show acceptable service records, al though it may conform to standard specifications now in use.

3. Improper treating.

4. Improper plant procedures in which the temperatures, pressures and time of treatment may be so drastic that the timbers may be seriously damaged and the value of the preservative lost.

5. The insufficient penetration and retention of the preservam tive for the specified desired treatment.

6. Improper handling of timbers after treatment and during construction.

7. Inadequate inspection.

Realizing that adequate inspection will lessen some of the causes I mentioned, the Bureau is now in the process of publishing an inspection and preservation manual for engineers in the construction and maintenance of marine structures. This manual will be for Navy use and is expected to contain in one volume all the necessary data for use of Navy designers, constructors and maintenance engineers.

One of the headaches of the engineer is the selection of the material to be used in a marine structure. For the most part, the problem of deterioration and prevention of attack by marine organisms on narine structures falls into two classes: 
1. Those relating to the choice of the type of material and kind of pliling for installation in new structures.

2. Those relating to the deterioration or destruction of piling al ready in place.

Problems of the first type; that is, the choice of the most suitable type of piling for a particular installation, perhaps gives the average harbor expert more difficulty than any other of his numerous worries. It is well understood that each type of piling wich may be used has its merits or advantages. Among the major considerations in selection of the type of piling for a given location are:

1. The type of structure to be erected - open wharf, closed wharf, finger pier, marginal wharf, open pier, closed pier, quay or mooring dolphin.

2. An estimate of the maximum loads to be used for design purposes,

3. Therunit $\infty$ st of piles based on the estimated life of the structure, including tho original cost.

4. The length of piles which may be used.

5. Investigation of the possibility of piles being subjected to excessive current flow, ware action and the abrasive action of water-borne sand.

6. A study of harbor conditions, including corrosiveness of water to concrete and steel, as well as the possibility of infestation by marine borers.

7. The action of the soil in which the pilings are to be driven.

The selection of the materials going into a structure is of utmost importance. So, too, is the design of structures to prevent deterioration.

A review of the work which has been done in the past on design of structures for protection has changed the Navy's concept of conventional bracing design of structures. As a result of this change, bracing is now placed in such a way as to aroid its coming into contact with the water.

In designing timber structures exposed to marine borer attack, piling and underwater timbers should be thoroughly pressure-treated with 
creosote, They should be handled and driven under very close supervision for protection against any damage to the treated surface. Specifications for the protection of the piling after treatment should prohibit the use of cant hooks, dogs, chain slings, or any other mechanical handling device which might break the sealed surface of the treated area, thereby setting up a danger point for attack.

The designer should so design the structure as to prevent any boring of holes or tapping of piles within the water area. All such connections should be kept above the high-water nark where possible. Designers should also use great care in their designs to prevent any untreated timber from coming into contact with treated timbers, especial iy where the se parts may be submerged in alt water at any time. Specifications should also include provision for bolt hole treatment and repair of damaged surfaces.

The protection of atructures against attack after the timbers have been in place presents a problem to the engineer. There are methods which may be used, such as encasement in concrete, the replacement with new treated piles, and in some instances, the encasement in metal armor. If metel armor is used the problem of corrosion immediately enters the picture. The losses to the Navy have been great in the past. They have caused the engineer responsible for the design and maintenence of these types of structures a great deal of concern.

At this time I would like to discuss the research work that the Navy Department is sponsoring on methods of obtaining more positive means of prevention of deterioration caused by marine borers and the destruction the piling through decay.

The Navy has consistently sponsored a program of inspection and study which includes practically every $U$.S. Naval installation in the world. This work is being carried out by the Willian F. Clapp Laboratories of Duxbury, Massachusetts. It consists essentialiy of the replacement of test panels in waters of the harbors with periodic examination of these panels to determine whether infestation is occurring, the types of borers prevalent in that area, and the breeding season of the borers, as well as the intensity of attack at various seasons of the year.

This work has been carried out over many years and the results have been compiled in a harbor report.

In addition to the ecological studies being carried on with the clapp Laboratories, the Bureau is also sponsoring a series of studies at the 
Dniversity of Miami Marine Laboratory, Coral Gables, Florida. These studies cover the physiological aspects of the borers. Fron these studies we hope to find better ways of protecting our wooden structures from marine borer attack, through a deeper knowledge of their general structure, feeding habits and their reaction to treatments of various types. The information which has been gathered so far by various approacines shows promise that the research will be more than worth the expenditure which is being made on the se studies.

In addition to the physiologicel studies, the University of Miarti is also cooperating with the Javal Research laboratory by making b10assays of various elements extracted from creosote. This effort is directed at devising a nore positive method of determining when creosote is of a grade which would be effective in protection against the inroads of the borers. These studies may result in changes in the present specifications for creosote materials.

The Haval Research Laboratory is making studies of creosotes and analyzing and extracting various groups of elements.

The Bureau is also pponsoring research at the Navel Civil Ingineering Research and Braluation Laboratory at Port Hueneme using the spectroscopic method of evaluation of the purity of the creosote. These show promise of being very valuable in determining whether creosotes have been diluted or whether, in their distil tation, certain important elements hare been inadvertantly excluded from the distilled product. The Bureau feeling is that adequate specifications and inspection of the timbers wich will be treated for use in marine structures are highly important.

In order to devise methods of prolonging the life of the structures, the continuing of long-range research program on the constituent parts of creosotes and their effect is absolutely necessary.

The Navy has been and still is greatly concerned in ondeavoring to improve the present specifications for creosoting materials. Accordingly, a good deal of research is being done at the present time in order to try to obtain a more positive specification for the treatment of waterfront structures which will insure the selection of materials to give the longest service.

We have come a long way since the days when the ravages of marine borers remained uncheaked due to lack of scientific knowledge.

We have made great strides in devising scientific techniques to cope with marine bo rer attacks. Despite these advances, there are still further problems to be solved for inproving our present methods and devising new methods to protect our structures. 